\title{
LAND CAPABILITY EVALUATION FOR CROP PRODUCTION USING REMOTE SENSING, GIS AND GEOSTATISTICS IN RIETFONTEIN, NORTH WEST PROVINCE OF SOUTH AFRICA
}

\author{
AVALIAÇÃO DA CAPACIDADE PRODUTIVA DE TERRAS PARA A PRODUÇÃO AGRÍCOLA USANDO \\ SENSORIAMENTO REMOTO, SIG E GEOESTATÍSTICA EM RIETFONTEIN, PROVÍNCIA NOROESTE DA ÁFRICA \\ DO SUL
}

Tabaro Kabanda

North-West University (NWU), Mmabatho, North West Province, Africa do Sul, kabandatabaro@gmail.com

\begin{abstract}
Land capability evaluation is important in arid and semi-arid environment as environmental resources need to be sustainably used. Land capability evaluation for agriculture assesses the land performance for a specific use of crop production. The objective of this research is to establish the potential role of remote sensing (RS) and GIS in spatial planning for arable agriculture in a communal land use setting of North West Province. The primary data were obtained from soil samples collected to $1 \mathrm{~m}$ depth and secondary information was acquired from the remotely sensed data (SPOT 5). The factors taken into consideration were soil texture, soil depth, clay fraction, $\mathrm{pH}$ and land use/land cover. Weighted overlay was used to combine all the parameters and produce a final capability map for sorghum and sunflower at Rietfontein farm. The results show that sorghum cultivation is suitable while sunflower is marginally suitable for cultivation. The study demonstrates that the farm can be categorized into spatially distributed agriculture potential zones based on the parameters. This study provides knowledge and encourages local communities to use land obtained through land reform sustainably and ensure food security in the country.
\end{abstract}

Keywords: GIS, Remote sensing, soil mapping, thematic maps, land capability, semi-arid environment, Agriculture

\section{RESUMO}

A avaliação da capacidade produtiva de terras se faz importante em ambientes árido e semiárido, assim como recursos ambientais nesses ambientes devem ser utilizados de forma sustentável. O processo de avaliação da produtividade de terra para o cultivo avalia o desempenho do solo com foco específico na produção de grãos. O objetivo desta pesquisa é estabelecer o potencial do Sensoriamento Remoto (SR) e dos Sistemas de Informações Geográficas (SIGs) para o planejamento espacial para agricultura arável em um cenário de amplo uso de terras na Província Noroeste da África do Sul. Os dados preliminares foram obtidos a partir de amostras coletadas a um metro de profundidade e informações secundárias foram obtidas a partir de dados de sensoriamento remoto (SPOT 5). Os fatores levados em consideração foram a textura e a profundidade do solo, percentual de argila, pH e uso da terra e cobertura da terra. Usou-se sobreposição ponderada para combinar todos os parâmetros e para produzir um mapa definitivo de capacidade produtiva para o cultivo de sorgo e girassol na fazenda Rietfontein. Os resultados demonstram que o sorgo é adequado para o cultivo, enquanto que o girassol é marginalmente adequado. O estudo demonstra que a fazenda pode ser categorizada em zonas potenciais de agricultura espacialmente distribuídas, baseando-se em parâmetros. $O$ estudo fornece conhecimentos e encoraja as comunidades locais para o uso sustentável da terra de áreas reformadas e para garantir a segurança alimentar no país.

Palavras-chave: SIGs (Sistemas de Informações Geográficas), Sensoriamento Remote, mapeamento do solo, mapas temáticos, capacidade produtiva do solo, ambiente semiárido, Agricultura.

Artigo recebido para publicação em março de 2015

Artigo aceito para publicação em junho de 2015

\section{INTRODUCTION}


Land evaluation has usually been predominantly based on soil resource inventories, commonly called soil surveys. The method of determining the land feature from soil characteristics is largely by evaluating and alignment of soil types in orders and classes according to their ability which may range from suitable (that symbolises a land with a sustainable usage) to inappropriate (which specifies a piece of land quality not allowing the considered agricultural use), or are not enough for sustainable outcomes. Hence, the objective of land capability evaluation is to predict the inherent capability of land in order to support the specific land use for long periods of time without deterioration (Bandyopadhyay, 2009).

Useful capability assessments cannot exclusively be centred upon biophysical resource information, other factors should be included such as scale dependent localized economies, and social factors such as demographics. The GIS required to service such research has to integrate high functionality and a capability to work effortlessly with both raster and vector data arrangements. Tabular information from various sources such as census and agricultural statistics, raster image data and vectorised output field data all supplement features to the overall study. GIS-based multi-criteria evaluation can be thought of as a process that combines and transforms spatial and a spatial data (input) into a resultant decision (output) (Malczewski, 2004).

Land reform plays an important part in the national development strategies, which is designed to reduce rural disparity, refining agricultural efficiency, provide food security and growing revenues and general wellbeing of the rural inhabitants. Owing to a $32 \%$ population growth since 1994 and only a 9\% increase in agriculture production, South Africa needs to produce at least $44 \%$ more food than that produced in 1994 (Hall, 2010). Thus there is a need for a complete reorganisation of the agricultural sector, with successful black commercial farmers making profits on their newly acquired land by producing economical and quality food. The aim of this research is to establish the potential role of remote sensing (RS) and GIS in spatial planning for arable agriculture in a communal land use setting. This study provides a methodology for land capability evaluation, where the results can be reproduced in areas with similar biophysical conditions. 


\section{Description of the study area}

Figure 1 shows a map of the Rietfontein farm, located near Coligny. Study area falls within Carletonville Dolomite Grassland, this is a species-rich mosaic of plant community types such as Aristida congesta and Brachiaria serrate occurring on undulating plains dissected by rocky chert ridges (Hoare, 2008).

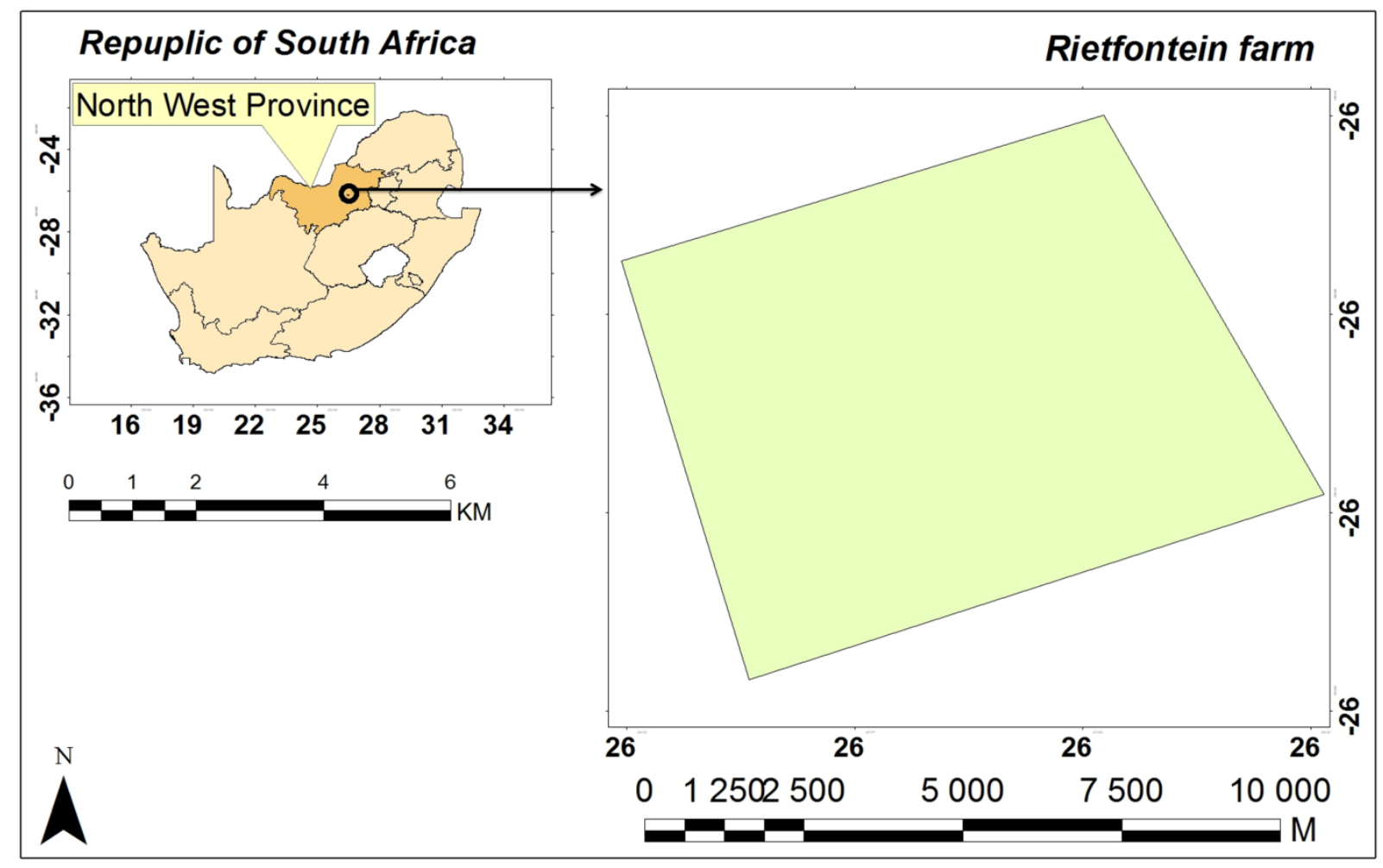

Figure 1. Map of Rietfontein farm in North West Province, South Africa.

\section{MATERIALS AND METHODS}

\section{Remote sensing data}

SPOT 5 HRG was obtained from South African National Space Agency (SANSA) at a preprocessing level (Level IA) at which radiometric and geometric corrections were required. The SPOT images underwent radiometric correction by computing the reflectance at the Top of the Atmosphere (TOA) 
for each image, in order to account for the variation in the relative positions between the sun, the earth and the satellite (Elsharkawy, 2012). Converting the Digital Numbers (DN) to Top of Atmosphere reflectance $(\rho)$ was done using equation 1 and 2 (Clark et al, 2010). Radiance (L $\lambda$ ) values (expressed as $\mathrm{W} m-2 \mathrm{sr}^{-1} \mu \mathrm{m}-1$ ) is computed using Equation 1, with gain (G) and offset (B) values that were supplied in the image metadata. Then reflectance $(\rho)$ values were computed for the two bands using equation (2).

$$
\begin{aligned}
& \text { Radiance }(L \lambda)=\frac{D N}{G}+B \\
& \rho=\frac{\pi L \lambda d^{2}}{E \operatorname{sun}_{\lambda} \cos \theta_{s}}
\end{aligned}
$$

Where $\rho$ is the reflectance, $L \lambda$ is the spectral radiance at the sensor's aperture ( $\mathrm{W} \mathrm{m}-2 \mathrm{sr}-1 \mu \mathrm{m}-1$ ), $\mathrm{d}$ is the date corrected earth-sun distance (astronomical miles) Esund is the SPOT sensor- and bandspecific equivalent solar irradiance (SPOT 5 HRG 2 band 2: Esun $\lambda=1575 \mathrm{~W}$ m-2 $\mu \mathrm{m}-1$, SPOT 5 HRG 2 band 3: Esun $\lambda=1047 \mathrm{~W} \mathrm{m-2} \mu \mathrm{m}-1$ ), and $\theta \mathrm{s}$ is the solar zenith angle.

To remove any geometric distortions in the SPOT 5 imagery, the images were registered to a UTM map projection (zone 35S, datum WGS84) using a nearest neighbour resampling routine a sub-pixel root mean square error was achieved for each image (Lillesand et al, 2008). Supervised classification was done using ground checkpoints and digital topographic maps of the study area. The area was classified into 4 main classes: water, crop land, woodland and bare land. Training sites were located and circumscribed by polygonal boundaries as shown in Figure 2. For each class outlined, mean values and variances of the digital numbers (DNs) for each band used to classify, were calculated from all pixels enclosed in the site. 


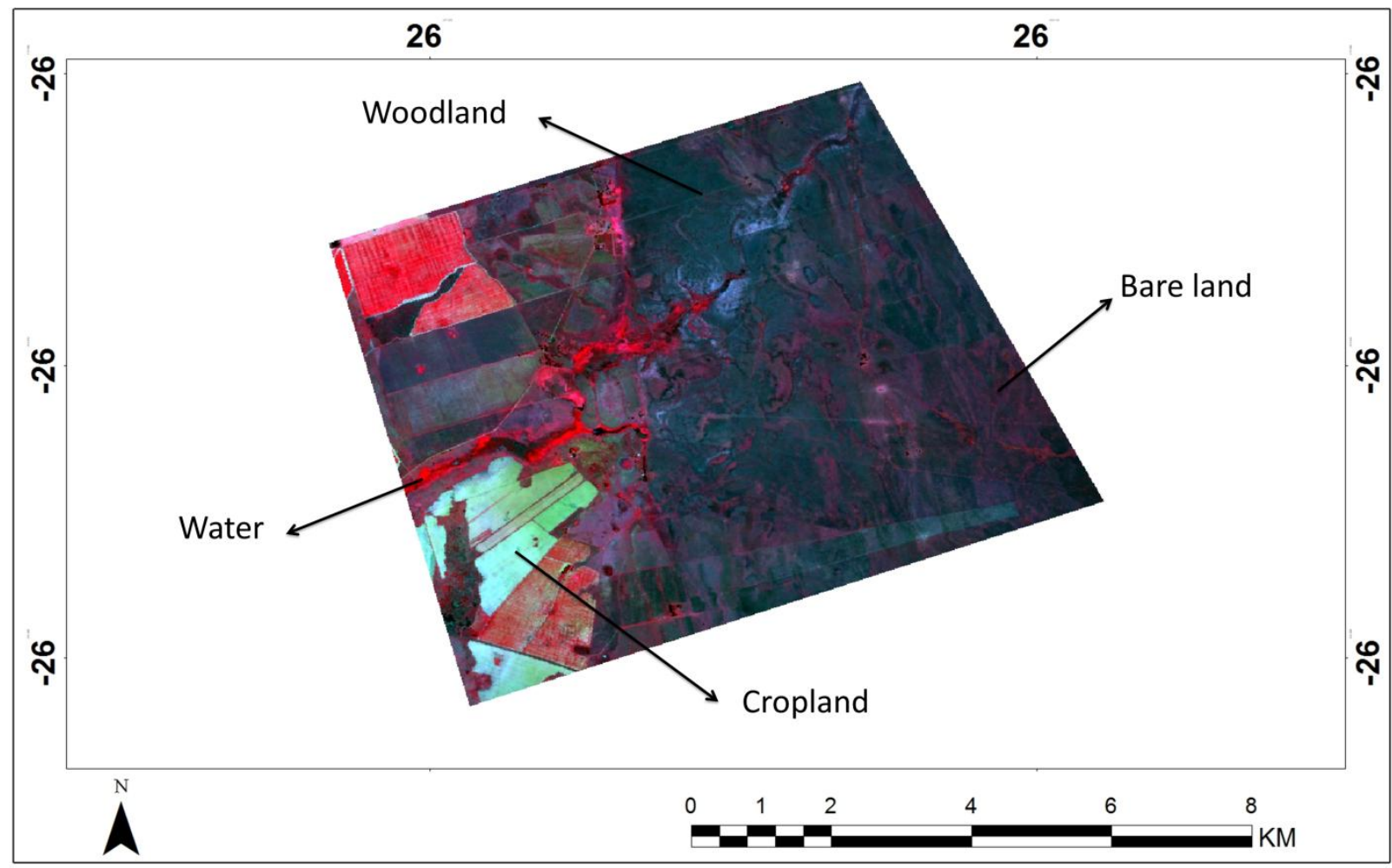

Figure 2. Map Classes on SPOT 5 HRG of Rietfontein farm.

The training points were proportionally distributed for each cover type. Training samples were gathered from more than 30 points as signatures for the supervised classification. A signature is a set of data that defines a training sample or cluster and corresponds to a class in a classification process (ERDAS Field guide, 2005). Following signature creation, the signature separability between the classes was evaluated using a Transformed Divergence measurement and viewed in a feature space plot. Signature separability is a statistical measure of the spectral distance between two signatures and can be calculated for any combination of bands that is used in a classification, enabling bands not useful in a classification to be ruled out (Bourne and Graves, 2001). Rietfontein farm had an average and minimum separability measure of 2000 and 2000. Accuracy assessment was carried out using 260 points. Congalton (1991) states that it has been shown that more than 250 reference pixels are needed to estimate the mean accuracy of a class to within plus or minus five percent. Topographical map (1:50 000) of 2014 and field work data using a hand-held global positioning system with an accuracy of $4 \mathrm{~m}$ were used as a reference for the images. Table 1 shows the error matrix for the classification of Rietfontein satellite imagery, the results show an accuracy of $88.46 \%$ and the overall 
Kappa statistics was 0.8050. Kappa statistic, $\kappa$, is an degree of agreement between categorical variables.

\begin{tabular}{|c|c|c|c|c|c|c|c|}
\hline & & \multicolumn{5}{|c|}{ REFERENECE DATA } & \multirow[b]{2}{*}{ User accuracy (\%) } \\
\hline & & Wo & C & WA & B & Total & \\
\hline \multirow{5}{*}{ 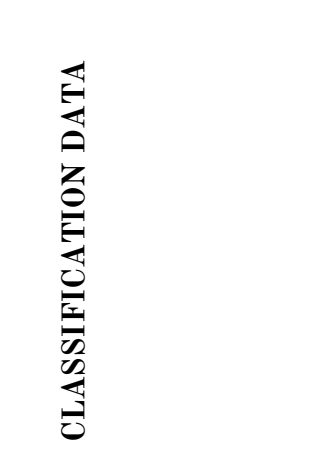 } & Wo & 138 & 4 & 0 & 6 & 148 & 93.24 \\
\hline & C & 6 & 27 & 0 & 3 & 36 & 75.00 \\
\hline & WA & 0 & 4 & 8 & 0 & 12 & 66.67 \\
\hline & B & 4 & 3 & 0 & 57 & 64 & 89.06 \\
\hline & Total & 148 & 38 & 0 & 66 & 260 & \\
\hline Producer accuracy (\%) & & 71.05 & 62.50 & 100.0 & 86.36 & & Overall accuracy $=88.46 \%$ \\
\hline
\end{tabular}

Table 1. Error Matrix for the classification of the Rietfontein (2013-02-17).

Legend: WA-Water, C-Crop land, B-Bare land, WO - Woodland

\section{Soil data collection}

A detailed soil survey was done throughout the study area covering $53 \mathrm{~km}^{2}$, between March and May of 2014. Soil samples were collected and analysed. Soil samples were collected to a depth of $100 \mathrm{~cm}$ and FAO (2007) was followed to classify the different soils of the studied area. Soil fertility was assessed through physical and chemical analyses. The particle size distribution of a soil sample is determined by sieve analysis, in sieve analysis the soil sample is separated by sieves with different aperture sizes. Usually a sieve analysis involves a nested column of sieves with wire mesh cloth (screen) and a given weighed sample is emptied into the top sieve which has the largest screen openings and this decreases with each lower sieve in the column than the one above until the base, called the receiver (Otieno, 2013). The entire nest is then agitated, and the material whose diameter is smaller than the mesh opening passes through the sieves and after the aggregate reaches the pan, the 
amount of material retained in each sieve is then weighed (Jamali, 2014). The Wentworth grade scale (phi $(\Phi)$ ) is then used to grade the grain size particle through transforming the millimetre value by taking the negative of its logarithm in base 2 to produce simple whole numbers.

Some of the selected physical and chemical properties of soils were interpolated using the Kriging method. The interpolation predictions from Kriging are relatively accurate compared to other interpolation techniques like Inverse Distance Weighting and it is a form of weighted local averaging that provides estimates of values at unrecorded places without bias and with minimum and known variance (Burgess and Webster 1980; Gotway et al, 1996). Kriging depends upon a semivariogram which considers spatial relationship and distance.

The semivariogram $\Upsilon(\mathrm{h})$ is described in equation 3 (Kerry et al, 2010).

$$
\Upsilon(\mathrm{h})=\frac{1}{2 N(h)} \sum_{i=1}^{N(h)}\left[z\left(x_{i}\right)-z\left(x_{i}+h\right)\right]^{2}
$$

Where $\mathrm{Z}\left(x_{i}\right)$ represents the measured value of the soil property at location $x_{i}, \Upsilon(\mathrm{h})$ is the semivariogram for a lag distance $\mathrm{h}$ between observations $\mathrm{Z}\left(x_{i}\right)$ and $\mathrm{Z}\left(x_{i}+h\right)$, and $\mathrm{N}(h)$ is the number of data pairs separated by a lag distance equal to $h$.

\section{Crop water requirement for sustainable land use}

Calculation of the crop water requirement is carried out in CROPWAT model by integrating the appropriate climate and rainfall data sets, together with the crop files and the corresponding planting dates. The amount of water required to compensate for the evapotranspiration loss from the cropped field is defined as the crop water requirements (FAO, 2007). CROPWAT is used as a practical tool to carry out standard calculations for reference evapotranspiration, crop water requirements and crop irrigation requirements, and more specifically the design and management of irrigation schemes (FAO, 2007). The input climatic data required by the model include monthly temperature (maximum and minimum), relative humidity, sunshine hours and wind speed. The crop data input includes the length of initial, development, mid-season and late-season crop growth stages, crop coefficient values for 
these four stages and planting date. Equation 4 shows the crop water requirement (CWR) for the crop evapotranspiration under standard conditions i.e. no limitations are placed on crop growth such as water shortage, diseases and weeds.

$$
\text { ETcrop }=\text { Kc x ETo }
$$

Where: $\mathrm{ETcrop}=$ crop evapotranspiration in $\mathrm{mm} /$ day, $\mathrm{Kc}=$ crop coefficient, $\mathrm{ETo}=$ potential crop evapotranspiration in $\mathrm{mm} /$ day

\section{Land capability assessment}

Climatic and soil requirements data were used for sunflower and sorghum with consultation from farmers and available literature from Department of Agriculture, Forestry and Fisheries in South Africa (Department of Agriculture, Forestry and Fisheries, 2010). Sunflower and sorghum are suited for the North West climatic conditions and produce high annual yield. The ARCGIS software package was used for creation of digital database and used for data integration and analysis. Thematic layers of land cover, soil fertility, soil depth, texture and clay content produced from the database were overlaid to produce a final capability map. Thematic layers were reclassified and weighted overlay technique applied to analyse the different parameters. Table 2 shows the weights and ratings assigned to land capability parameters for sunflower. Weight assignment is determined by consulting the opinions of experts and the Department of Agriculture literature. Equation 5 shows the equation used for the assessment of land capability.

$$
\begin{gathered}
\mathrm{LSP}=0.2(\mathrm{LU}) \mathrm{i}=1-4+0.1(\mathrm{SL}) \mathrm{i}=1-4+0.2(\mathrm{D}) \mathrm{i}=1-3+0.2(\mathrm{~T}) \mathrm{i}=1-5+0.2(\mathrm{pH}) \mathrm{i}=1-312+ \\
0.05(\mathrm{C}) \mathrm{i}=1-3+0.05(\mathrm{DR}) \mathrm{i}=1-3
\end{gathered}
$$

where LSP is the numerical index of the land suitability, LU is the land use/land cover variable (with classes 1-4), SL indicates slope on (with classes 1-4), D indicates depth factor (with classes 1-3), $\mathrm{pH}$ indicates soil $\mathrm{pH}$ (with classes 1-3), T indicates texture (with classes 1-5), C indicates clay percentage (classes 1-3) and DR indicates drainage (with classes 1-3). 


\begin{tabular}{|c|c|c|c|}
\hline \multicolumn{4}{|l|}{ SUNFLOWER } \\
\hline Variables & Classes & Ratings & Land capability \\
\hline \multirow{4}{*}{$\begin{array}{l}\text { Land use/land cover } \\
\text { (weight=0.2) }\end{array}$} & Water & 2 & Not suitable \\
\hline & Agriculture land & 10 & Good \\
\hline & Bare land & 8 & Fair \\
\hline & Wood land & 10 & Good \\
\hline \multirow[t]{4}{*}{ Slope (weight $=0.1$ ) } & $0-4 \%$ & 10 & Good \\
\hline & $4-8 \%$ & 8 & Fair \\
\hline & $8-12 \%$ & 4 & Poor \\
\hline & $>12 \%$ & 2 & Not suitable \\
\hline \multirow[t]{3}{*}{ Depth (weight $=0.2$ ) } & $>100 \mathrm{~cm}$ & 10 & Good \\
\hline & $80-100 \mathrm{~cm}$ & 8 & Fair \\
\hline & $<80$ & 8 & Fair \\
\hline \multirow[t]{3}{*}{$\mathrm{pH}$ (weight $=0.2$ ) } & $5.5-7.5$ & 10 & Good \\
\hline & $7.5-8.5$ & 6 & Moderate \\
\hline & $<4.5$ & 4 & Poor \\
\hline \multirow[t]{5}{*}{ Texture (weight $=0.2$ ) } & Clay loam & 10 & Good \\
\hline & Sandy loam & 8 & Fair \\
\hline & Clay (light) & 10 & Good \\
\hline & Sandy clay loam & 10 & Good \\
\hline & Sandy & 8 & Fair \\
\hline \multirow[t]{3}{*}{ Clay (weight $=0.05$ ) } & $10-20 \%$ & 10 & Good \\
\hline & $20-30 \%$ & 10 & Good \\
\hline & $>30 \%$ & 8 & Fair \\
\hline \multirow[t]{3}{*}{$\begin{array}{l}\text { Drainage } \\
\text { (weight }=0.05 \text { ) }\end{array}$} & Well drained & 10 & Good \\
\hline & $\begin{array}{c}\text { Moderately } \\
\text { drained }\end{array}$ & 8 & Fair \\
\hline & $\begin{array}{c}\text { Imperfectly } \\
\text { drained }\end{array}$ & 6 & Moderate \\
\hline
\end{tabular}

Table 2. Weights and ratings assigned to land capability parameters for sunflower

\section{RESULTS}

\section{Land use structure}


Figure 3 shows the land use classes of Rietfontein farm and these covers a total of $53 \mathrm{~km}^{2}$, with woodland accounting for $65.1 \%$ of the farm. Bare land covers $23.5 \%$ whilst cropland and water account for 5.3 and $6.2 \%$ respectively.

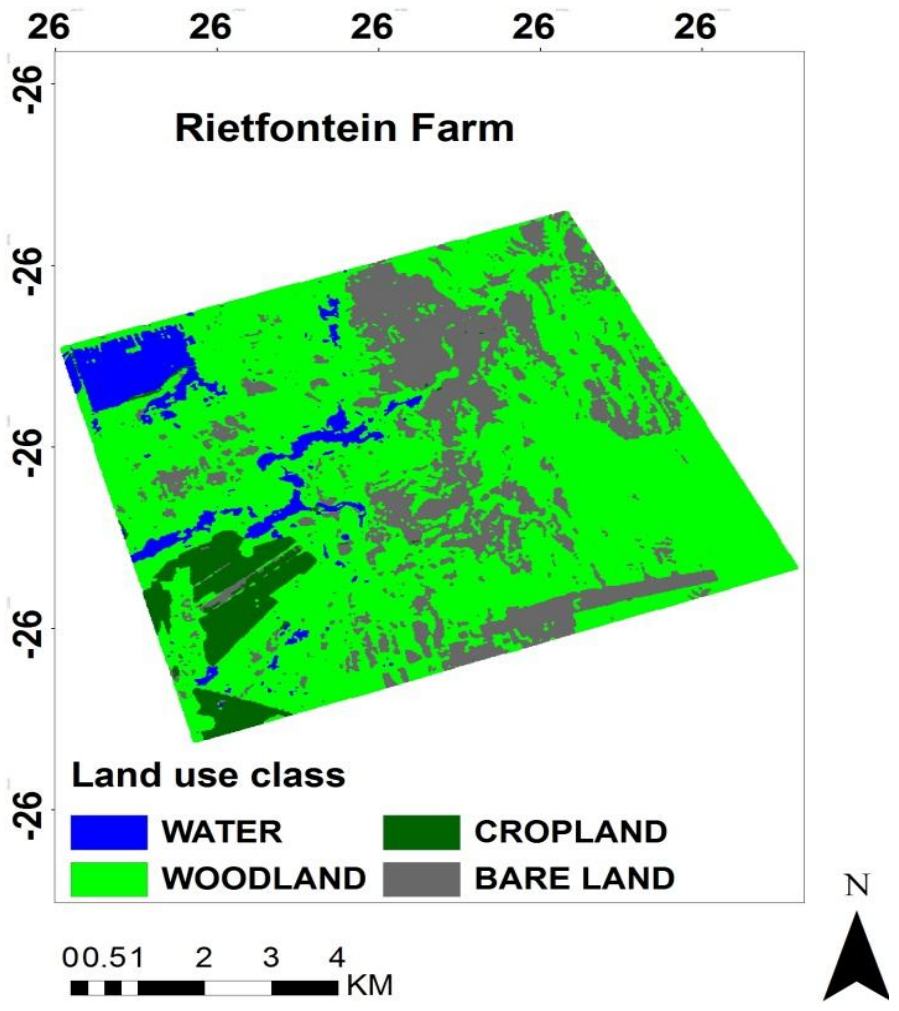

Figure 3. Land use classes of Rietfontein farm.

\section{Geostatistical analysis}

Geostatistical interpolation using the Kriging technique was used to estimate continuous properties within the sampled locations using the Spatial Analyst extension of ArcGIS. A Semivariogram function displays the assumption that features nearby tend to be more similar than features that are farther apart. Geostatistical analysis of the sampled soil properties display a parabolic behaviour which shows that variability increases very slowly with separation. This can be seen in the Figure 4, which shows the anatomy of a typical semivariogram in Rietfontein farm where soil properties exhibited spatial dependency. 

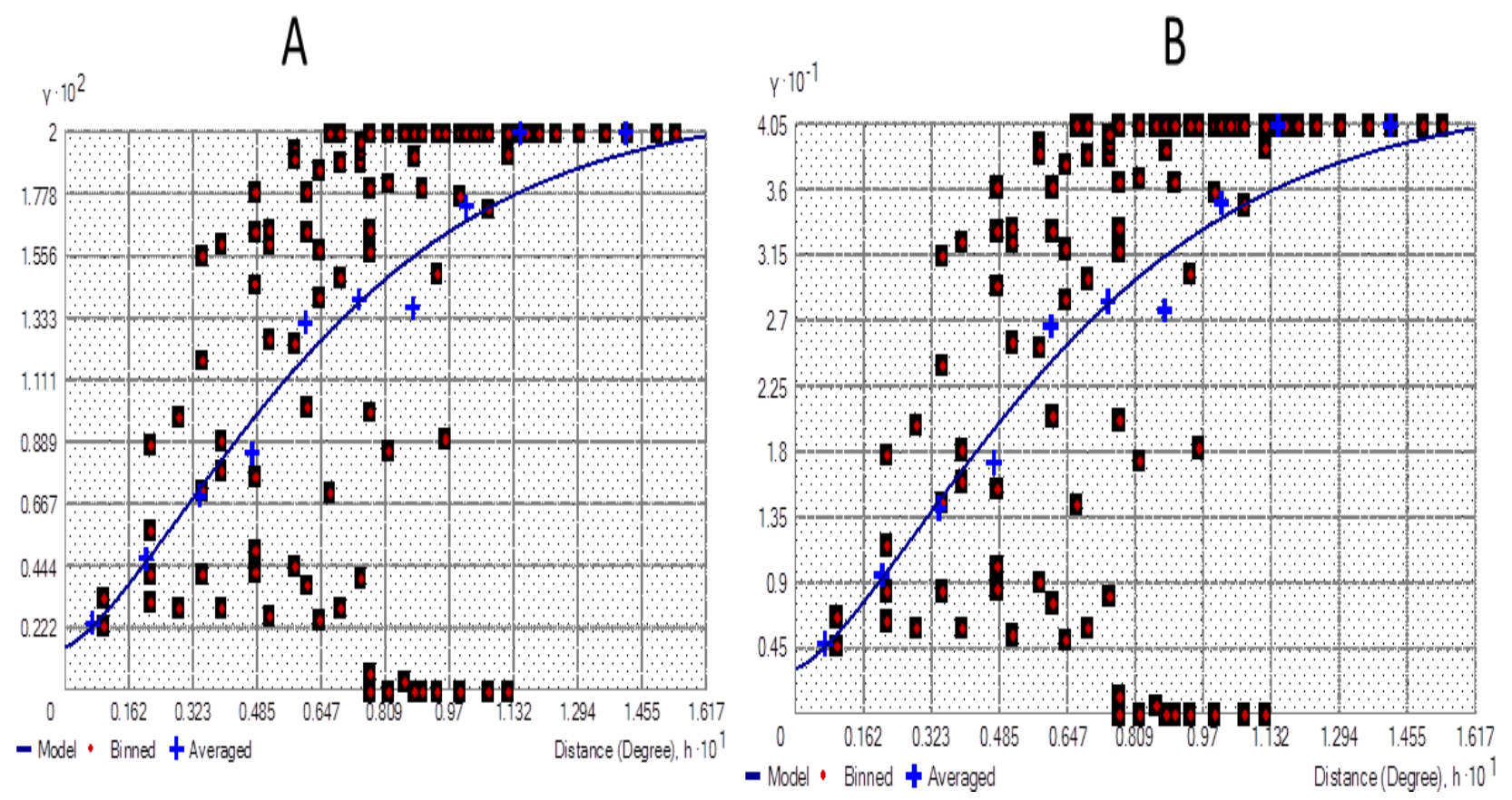

Figure 4. Semivariograms of soil $\mathrm{pH}(\mathrm{A})$ and depth (B) properties in the study area.

\section{Soil fertility analysis}

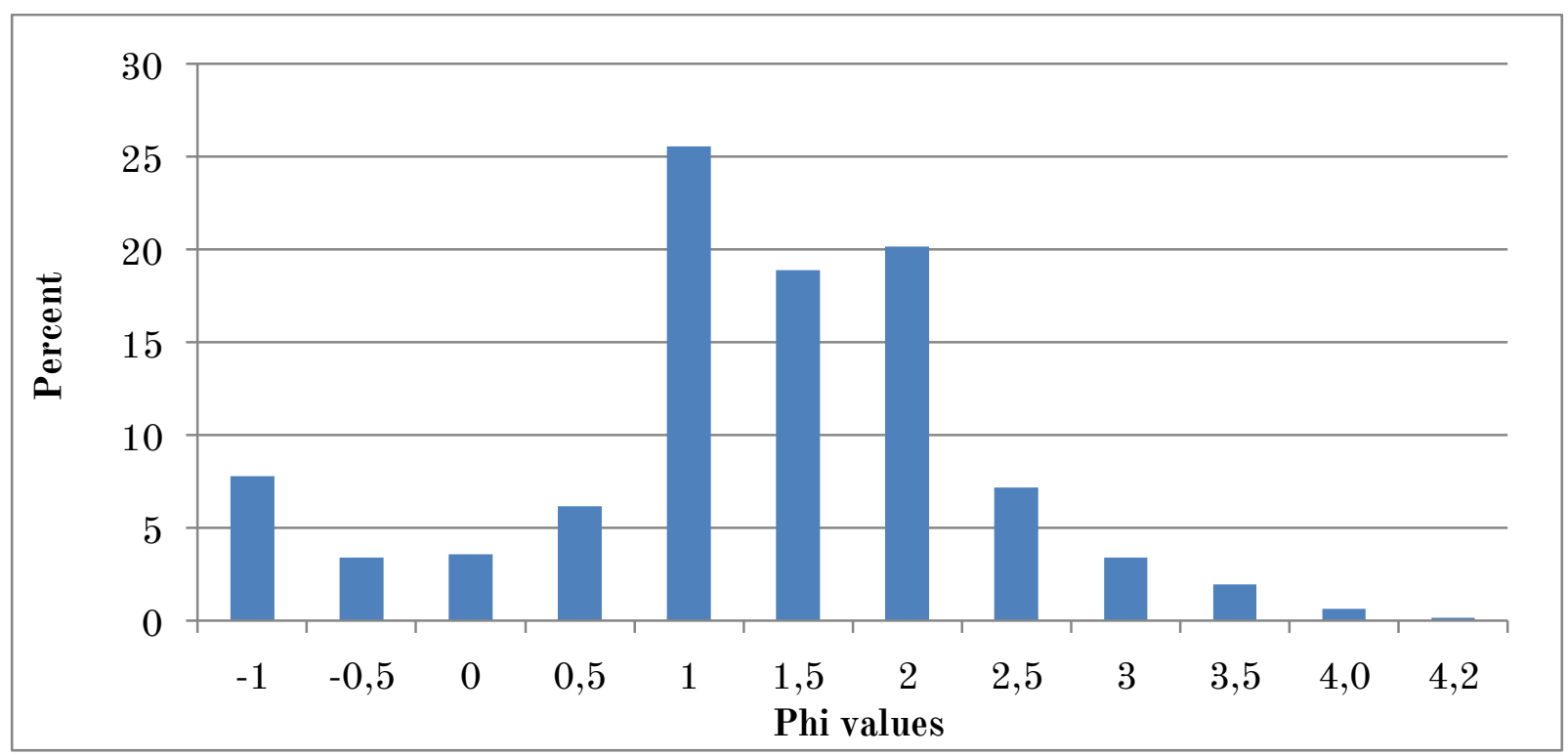

Figure 5. Percentage retained on each sieve.

Sieve analysis laboratory procedure is conducted to determine the textural class of soil samples. The cumulative percent retained is calculated by adding percent retained on each sieve on the basis of the 
total mass of the initial dry sample. Figure 5 indicates that majority of the soil settled 1 , according to the Wentworth grade this is regarded as medium sand. Sandy clay loam soil covers $27.17 \%$ of Rietfontein farm and loam makes up 72.83\%, loam soil is made up of other mixed particles of soil materials like sand, silt and clay. Table 3 shows the soil physical properties in Rietfontein farm.

\begin{tabular}{|l|l|l|l|l|}
\hline Soil texture & Drainage & Area $\left(\mathbf{k m}^{\mathbf{2}}\right)$ & $\mathbf{\%}$ & \\
\hline Loam & Imperfectly & 38.70 & 72.83 & Rietfontein Farm \\
\hline Sandy clay loam & Moderately Well & 14.44 & 27.17 & Rietfontein Farm \\
\hline
\end{tabular}

Table 3. Percentage retained on each sieve.

Crop cultivation mostly prefers loamy to sandy loam soil as such soil are easier to work with and need moderate irrigation (FAO, 2007). Moderately well drained soil covers $14.44 \%$ of Rietfontein farm while imperfectly drained soils make up 72.83\% (Figure 6A).

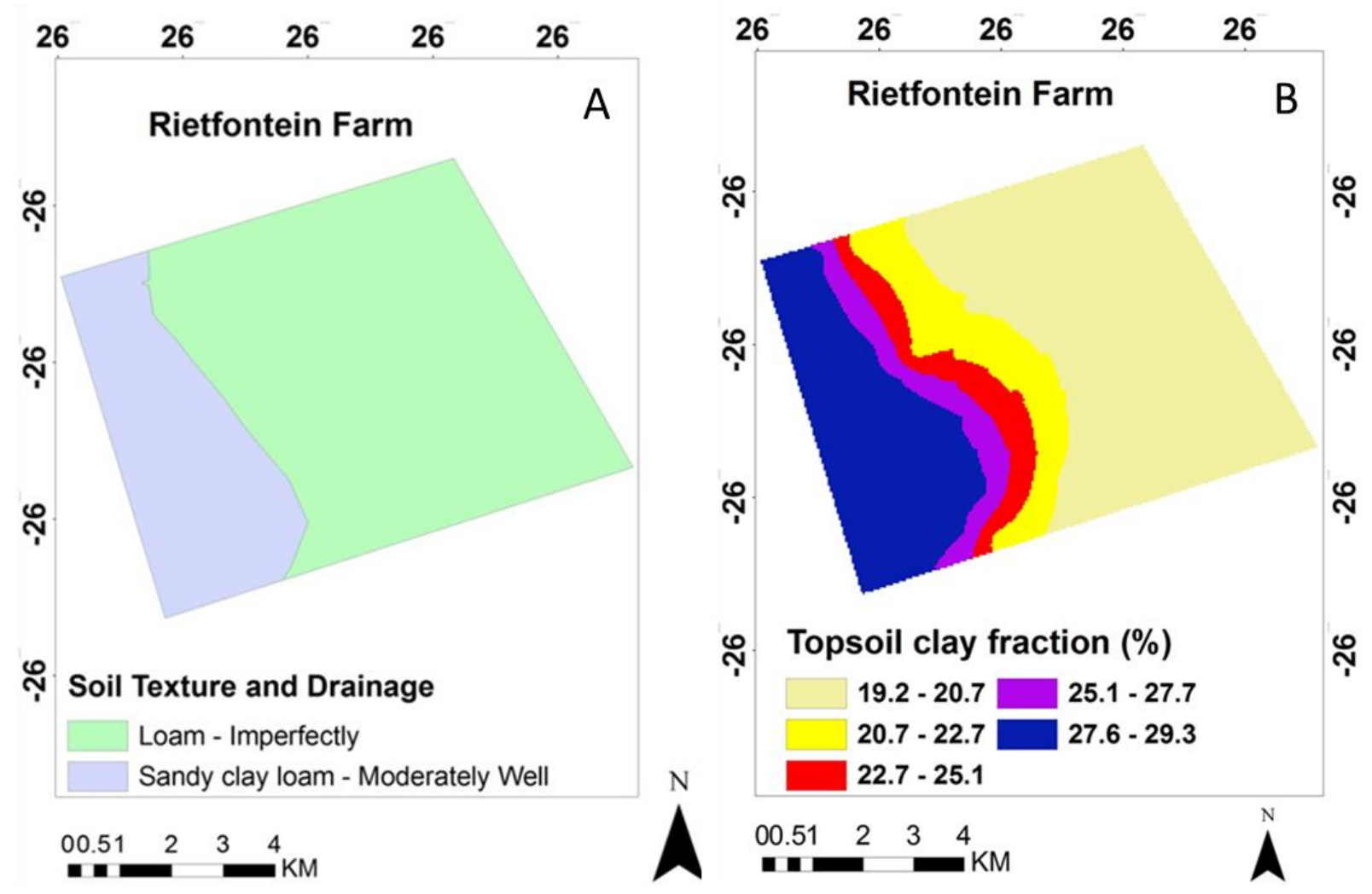

Figure 6. Soil texture and drainage (A) and clay fraction (B) in Rietfontein farm. 
Chemical properties

Soil $\mathrm{pH}$ is less varied in Rietfontein farm with ranges from 6.3 to 6.5. Haplic Lixisols soils generally have low cation exchange capacity and thus a higher $\mathrm{pH}$, in Rietfontein farm the $\mathrm{pH}$ is slightly acidic at 6.3 to 6.4 as seen in Figure 7. Eutric Leptosols (LPe) also display slightly acidic characteristic with a range from 6.4 to $6.5, \mathrm{LPe}$ are generally basic because of calcium carbonate presence.

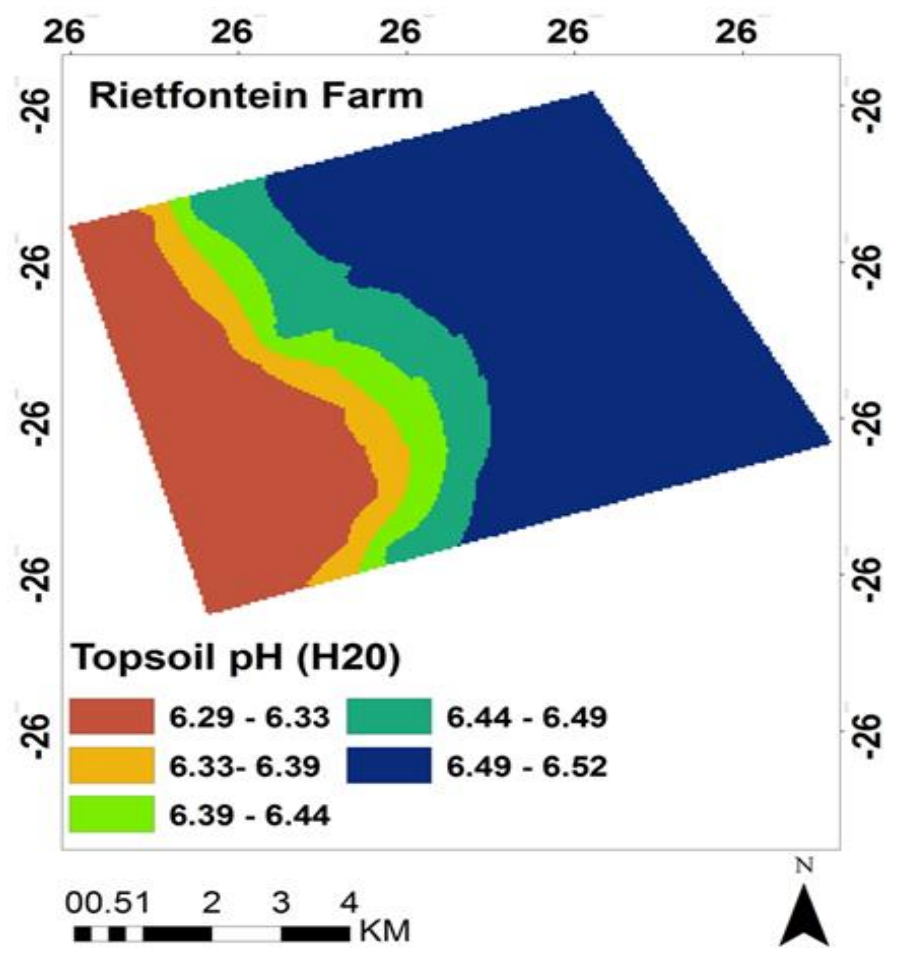

Figure \%. Soil pH in Rietfontein farm.

\section{Climate conditions}

Rietfontein farm is situated near Coligny and receives an annual amount of $512 \mathrm{~mm}$ in rainfall with the highest peak in December. Rietfontein farm experiences an average of $26.7{ }^{\circ} \mathrm{C}$ in temperature as seen in Figure 8. The climatic conditions in Coligny allow for cultivation of crops. This is due to optimum amount of rainfall $(500 \mathrm{~mm})$ and temperature (average high of $26.7^{\circ} \mathrm{C}$ and a low of $13{ }^{\circ} \mathrm{C}$ ) during the growing season between October to April. Sunflowers grow best when planted in midsummer to ensure that less moisture is lost from the soil during the crucial growing phases. 
Compared to other crops, sunflower performs well under dry conditions. This is probably the main reason for the crop's popularity in North West Province.

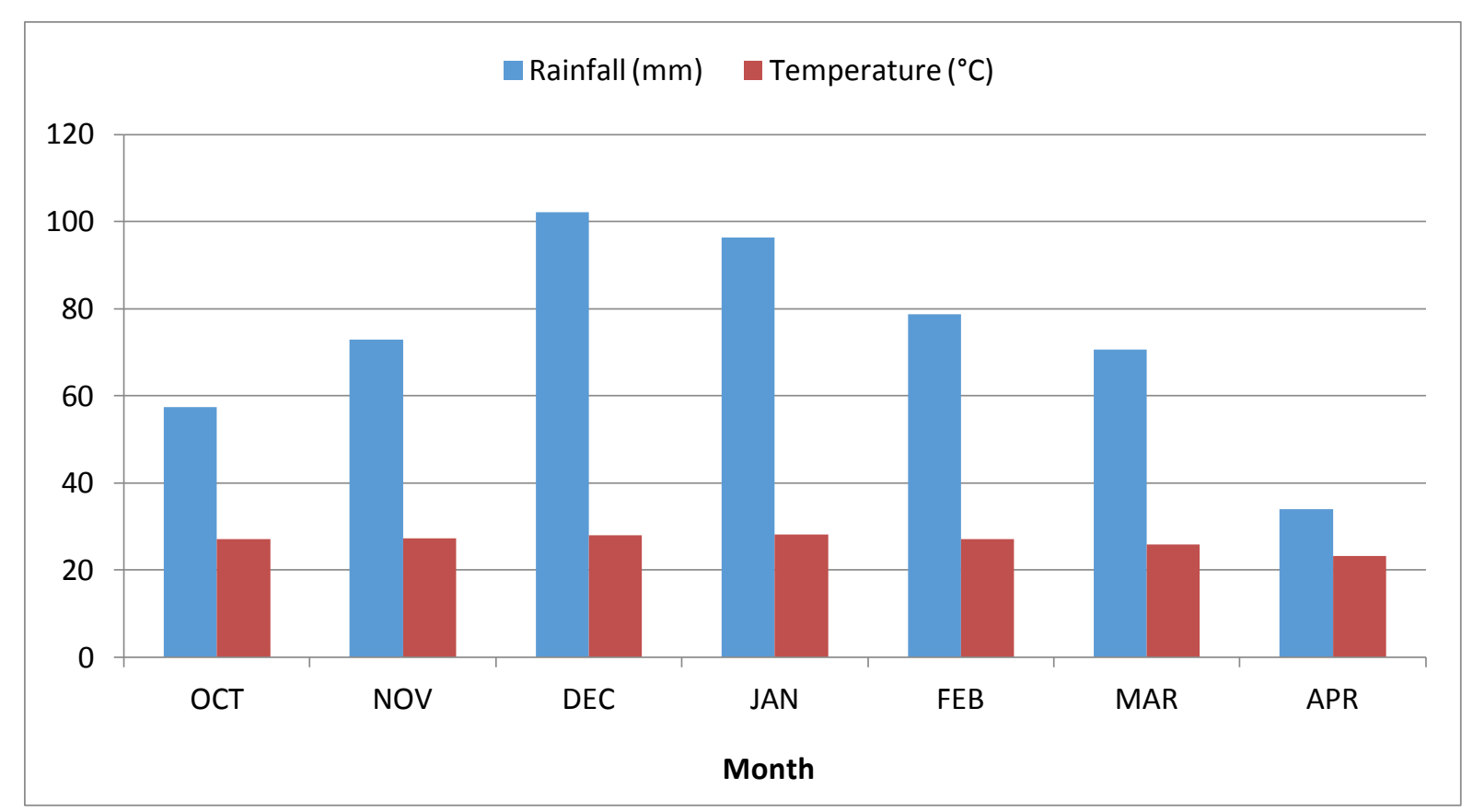

Figure 8. Monthly rainfall and temperature for the Coligny.

\section{Crop water requirement in rietfontein farm}

The crop water requirement generally peaked during mid-season and dropped during the late season.

The maximum crop water need is reached at the end of the crop development stage, which is the beginning of the mid-season stage, while during the late season stage dry harvested crops are allowed to dry out and sometimes even die and thus their water needs during the late season stage are minimal (FAO, 2007). Figure 9 shows the crop water requirement for Sorghum. 


\begin{tabular}{|c|c|c|c|c|c|c|c|}
\hline \multicolumn{3}{|c|}{ (3) Crop Water Requirements } & & & & & \\
\hline \multirow{2}{*}{\multicolumn{2}{|c|}{$\begin{array}{l}\text { ETo station } \\
\text { Rain station }\end{array}$}} & & & & \multicolumn{3}{|c|}{ Crop Sorghum } \\
\hline & & & & & \multicolumn{3}{|c|}{ Planting date $22 / 10$} \\
\hline \multirow[t]{2}{*}{ Month } & Decade & Stage & $\mathrm{Kc}$ & ETc & ETc & Eff rain & Irr. Req. \\
\hline & & & coeff & $\mathrm{mm} / \mathrm{day}$ & $\mathrm{mm} / \mathrm{dec}$ & $\mathrm{mm} / \mathrm{dec}$ & $\mathrm{mm} / \mathrm{dec}$ \\
\hline Oct & 3 & Init & 0.70 & 3.17 & 31.7 & 3.8 & 27.5 \\
\hline Noy & 1 & Init & 0.70 & 3.35 & 33.5 & 14.8 & 18.6 \\
\hline Noy & 2 & Deve & 0.74 & 3.71 & 37.1 & 21.5 & 15.6 \\
\hline Nov & 3 & Deve & 0.81 & 4.15 & 41.5 & 25.2 & 16.3 \\
\hline Dec & 1 & Deve & 0.87 & 4.61 & 46.1 & 28.1 & 18.0 \\
\hline Dec & 2 & Mid & 0.93 & 5.03 & 50.3 & 31.9 & 18.4 \\
\hline Dec & 3 & Mid & 0.94 & 5.08 & 55.9 & 37.5 & 18.4 \\
\hline Jan & 1 & Mid & 0.94 & 5.09 & 50.9 & 46.1 & 4.8 \\
\hline Jan & 2 & Mid & 0.94 & 5.10 & 51.0 & 52.9 & 0.0 \\
\hline Jan & 3 & Late & 0.90 & 4.79 & 52.7 & 47.4 & 5.3 \\
\hline Feb & 1 & Late & 0.75 & 3.90 & 39.0 & 41.5 & 0.0 \\
\hline Feb & 2 & Late & 0.60 & 3.04 & 30.4 & 37.9 & 0.0 \\
\hline \multirow[t]{2}{*}{ Feb } & 3 & Late & 0.50 & 2.44 & 7.3 & 11.0 & 0.0 \\
\hline & & & & & 527.4 & 399.8 & 143.0 \\
\hline
\end{tabular}

Figure 9. Crop water requirement for Sorghum.

Where: $\mathbf{I R}=$ Irrigation Requirement $(\mathrm{mm} / \mathrm{dec}), \mathrm{Ke}=$ Crop Coefficient and ETerop $=$ Crop Evapotranspiration $(\mathrm{mm} /$ day $)$, Eff rain $=$ Effective rain $(\mathrm{mm} / \mathrm{dec})$ and ETcrop $=$ Crop Evapotranspiration $(\mathrm{mm} / \mathrm{dec})$.

The reference crop evapotranspiration (ETo) of sunflower was at $469 \mathrm{~mm} / \mathrm{dec}$ while sorghum was at $527 \mathrm{~mm} /$ dec. The irrigation requirement was $73 \mathrm{~mm} / \mathrm{dec}$ for sunflower while sorghum had the highest value of irrigation requirement at $133 \mathrm{~mm} / \mathrm{dec}$. 
Rain station Lichtenburg
ETo station Lichtenburg

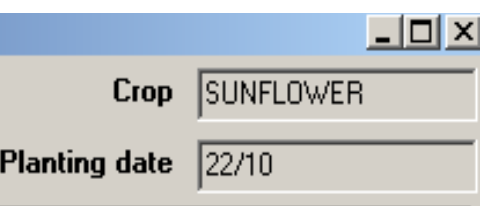

\begin{tabular}{|c|c|c|c|c|c|c|c|}
\hline Month & Decade & Stage & Kc & ETc & ETc & Eff rain & Irr. Req. \\
\hline & & & coeff & mm/day & mm/dec & mm/dec & $\mathrm{mm} / \mathrm{dec}$ \\
\hline Oct & $\mathbf{3}$ & Init & 0.35 & 1.59 & 15.9 & 3.8 & 11.6 \\
\hline Nov & $\mathbf{1}$ & Init & 0.35 & 1.67 & 16.7 & 14.8 & 1.9 \\
\hline Nov & $\mathbf{2}$ & Deve & 0.38 & 1.89 & 18.9 & 21.5 & 0.0 \\
\hline Nov & $\mathbf{3}$ & Deve & 0.53 & 2.71 & 27.1 & 25.2 & 1.9 \\
\hline Dec & $\mathbf{1}$ & Deve & 0.69 & 3.66 & 36.6 & 28.1 & 8.5 \\
\hline Dec & $\mathbf{2}$ & Deve & 0.86 & 4.66 & 46.6 & 31.9 & 14.7 \\
\hline Dec & $\mathbf{3}$ & Mid & 0.94 & 5.08 & 55.8 & 37.5 & 18.3 \\
\hline Jan & $\mathbf{1}$ & Mid & 0.94 & 5.09 & 50.9 & 46.1 & 4.7 \\
\hline Jan & $\mathbf{2}$ & Mid & 0.94 & 5.10 & 51.0 & 52.9 & 0.0 \\
\hline Jan & $\mathbf{3}$ & Mid & 0.94 & 4.99 & 54.9 & 47.4 & 7.5 \\
\hline Feb & $\mathbf{1}$ & Late & 0.87 & 4.54 & 45.4 & 41.5 & 3.8 \\
\hline Feb & $\mathbf{2}$ & Late & 0.64 & 3.28 & 32.8 & 37.9 & 0.0 \\
\hline Feb & $\mathbf{3}$ & Late & 0.43 & 2.12 & 16.9 & 29.3 & 0.0 \\
\hline
\end{tabular}

Figure 10. Crop water requirement for sunflower.

Where: IR = Irrigation Requirement $(\mathrm{mm} / \mathrm{dec}), \mathrm{Ke}=$ Crop Coefficient and ETerop $=$ Crop Evapotranspiration $(\mathrm{mm} /$ day), Eff rain $=$ Effective rain $(\mathrm{mm} / \mathrm{dec})$ and ETcrop $=$ Crop Evapotranspiration (mm/dec).

\section{DISCUSSION}

\section{Land capability evaluation for sunflower cultivation}

The Rietfontein farm is not favourable for the cultivation of sunflower as only $24.8 \%$ falls under highly to moderately suitable (Figure 11). The soil depth within this region is $100 \mathrm{~cm}$ and the sandy clay texture allows for growth of sunflower as soils with good water-holding capacity (clays) are preferred under dryland conditions (Department of Agriculture, Forestry and Fisheries, 2010). 


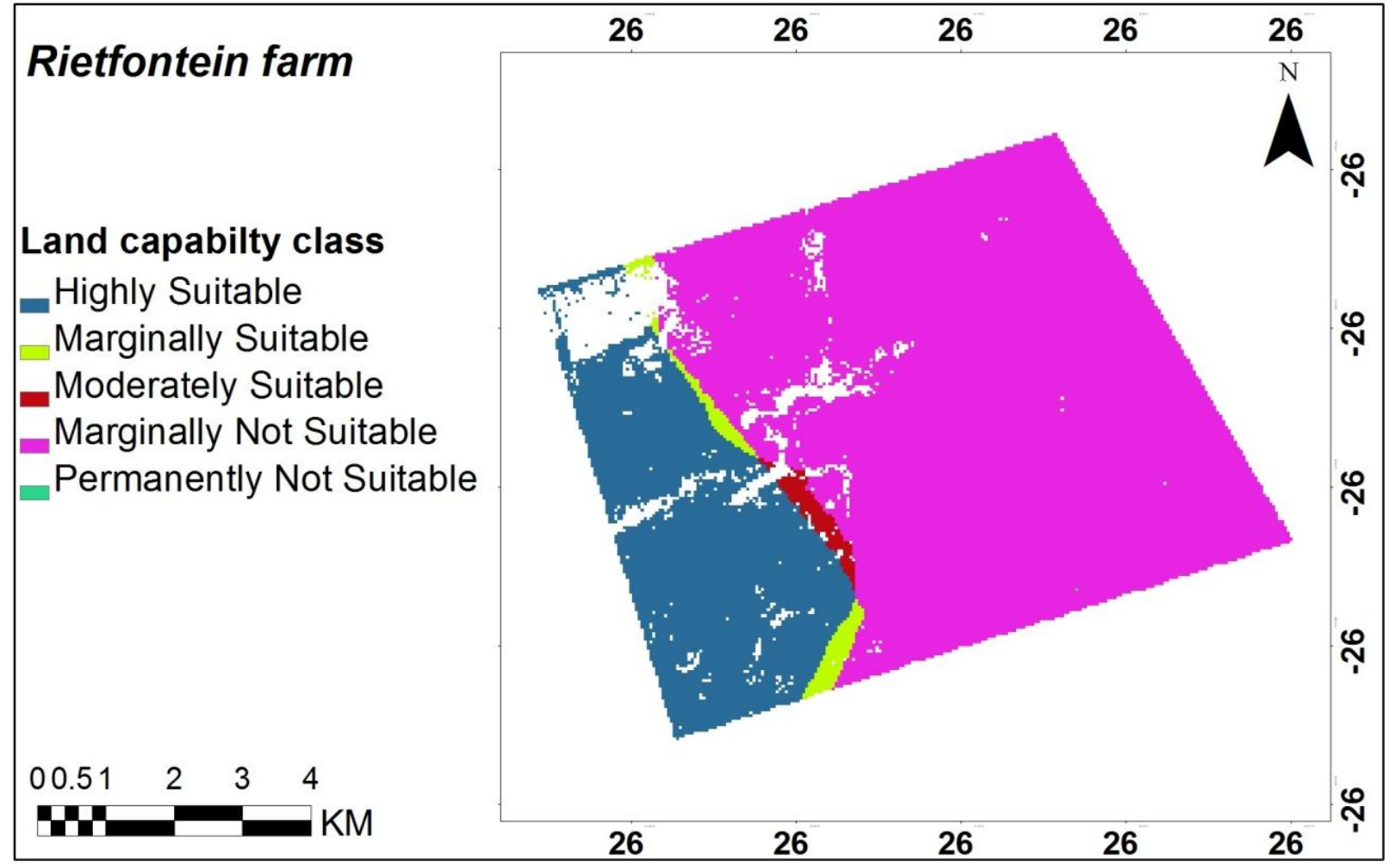

Figure 11. land capability classified map for sunflower.

\section{Land capability evaluation for sorghum cultivation}

The Rietfontein farm is not favourable for the cultivation of sunflower as only $24.8 \%$ falls under highly to moderately suitable (Figure 11). The soil depth within this region is $100 \mathrm{~cm}$ and the sandy clay texture allows for growth of sunflower as soils with good water-holding capacity (clays) are preferred under dryland conditions (Department of Agriculture, Forestry and Fisheries, 2010).

Sorghum is mainly grown on low potential, shallow soils with high clay content (Department of Agriculture, Forestry and Fisheries, 2010). Figure 11 show that 48\% of the farm is highly suitable (S1) while $52 \%$ is marginally suitable (S2) for sorghum cultivation. S2 soils are shallow with soil depth less than $50 \mathrm{~cm}$ and as sorghum is more tolerant of alkaline salts than other grain crops and can therefore be successfully cultivated on soils with a pH between 5,5 and 8,5 (Department of Agriculture, Forestry and Fisheries, 2010). 


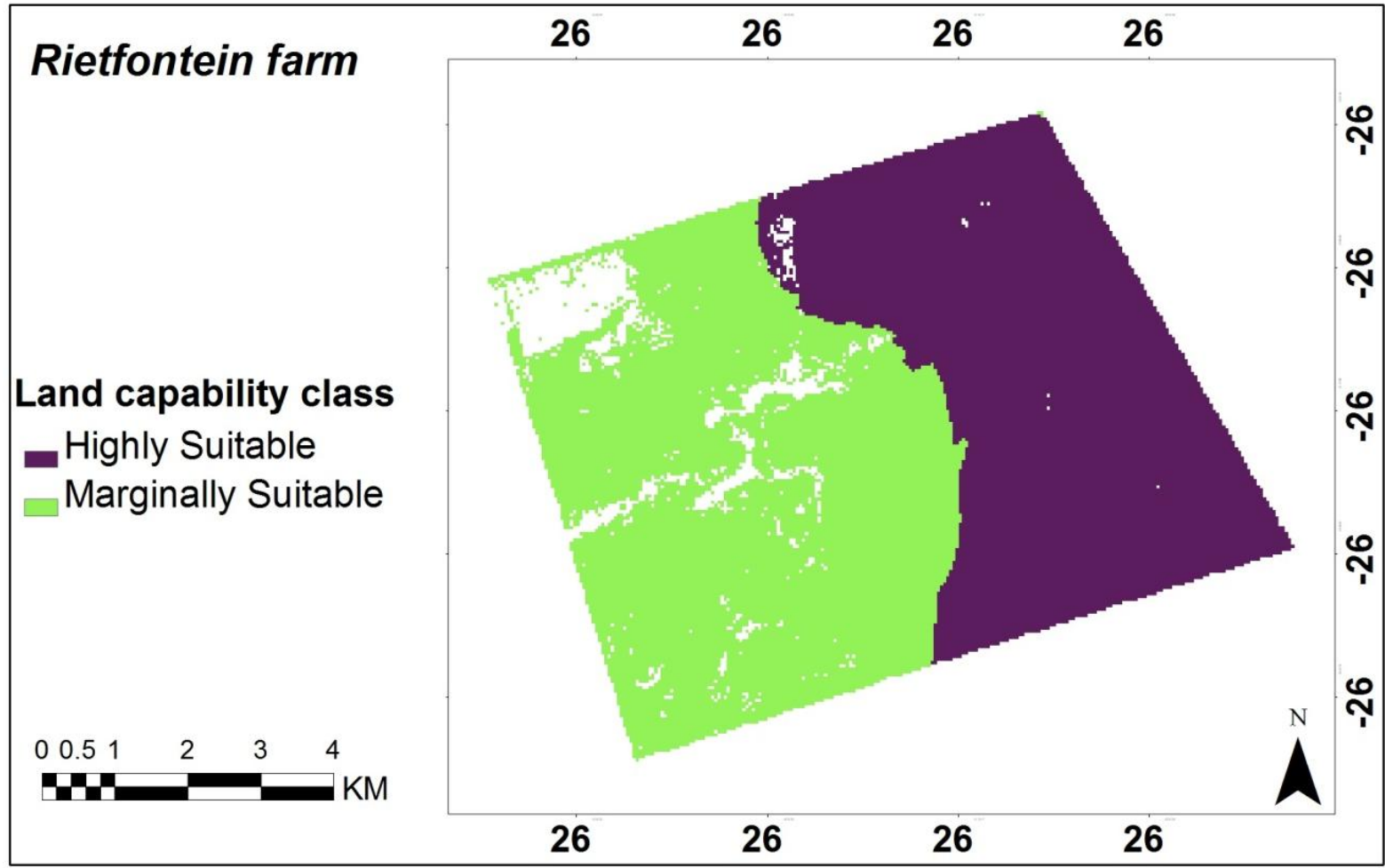

Figure 12. land capability classified map for sunflower.

\section{Land capability evaluation for sorghum cultivation}

Based on intensive field information and data analysis, this paper attempted to develop a methodology for land capability evaluation for agriculture using GIS modelling. The GIS based model considered the local biophysical variations and has been developed specifically for mapping agricultural land capability. The map provides spatial representation of the inherent capability of the land to support agriculture and is important for end users as it benefits the existing land users in determining the most appropriate management practices. The results showed that sorghum cultivation is suitable while sunflower is marginally suitable for cultivation. The crop water requirement was consistent throughout the growing period for both sunflower and sorghum. Data analysis shows that only $21 \%$ of drainage was imperfect, thus all crops had almost appropriate drainage conditions. Sorghum though, can better tolerate short periods of waterlogging compared to sunflower. Soil in the study area is generally not suffering in fertility. Increase in organic matter through fertilizers will massively upgrade fertility ratings and improve capability levels for sunflower and benefit sorghum. 
Results from geostatistical analysis confirm the importance of collecting information in every agricultural region within the study area. Although extrinsic factors such as the groundwater level and the drainage can affect the strong spatial dependency of soil properties as evidenced in the study site showing two characteristics. Community participation for implementing the most appropriate management practices is an important criterion for sustainable land use and the use of spatial analyses techniques in evaluating the land capability, allow producing multi-thematic maps, and provides the understanding on how to deal with these soils for sustainable agricultural use.

The evidence of the last 18 years suggests that after the acquisition of land by land reform beneficiaries, there is minimal support to new farmers. Land capability study as part of postsettlement support is necessary to long-term success for beneficiaries as the authorities and the farmers will have available information on the physical aspects of the various soils and their distribution in the land as well as a classification of their relative capability for agriculture.

\section{ACKNOWLEDGEMENT}

A bursary from North West University/NRF research fund facilitated this research. Besides, the authors wish to express their gratitude to the anonymous reviewers, who helped to improve this paper through their thorough review.

\section{REFERENCES}

BANDYOPADHYAY, S, AND JAISWAL, K. Assessment of land suitability potentials for agriculture using a remote sensing and GIS based approach. International Journal of Remote Sensing, v. 30, n. 4, p. 879-895, 2009.

BURGESS, T.M., AND WEBSTER, R. Optimal interpolation and isarithmic mapping of soil properties-I the semivariogram and punctual kriging. Journal Soil Science, v 31, p. 315-331, 1980.

BOURNE, S.G AND GRAVES, M.R. Classification of Land-Cover Types for the Fort Benning Ecoregion Using Enhanced Thematic Mapper Data. ERDC/EL TN-ECMI-01-1, U.S. Army Engineer Research and Development Center, Vicksburg, MS. 2001.

CLARK, B., SUOMALAINEN, J., AND PELLIKA, P. A comparison of methods for the retrieval of surface reflectance factor from multitemporal SPOT HRV, HRVIR, and HRG multispectral satellite imagery. Canadian Journal of Remote Sensing, v 36, p. 397-411, 2010. 
CONGALTON, R.G. A review of assessing the accuracy of classifications remotely sensed data. Remote Sensing of Environment, v. 37, p. 35-46, 1991.

DEPARTMENT OF AGRICULTURE, FORESTRY AND FISHERIES. Annual report 2010/11. Private Bag X246 Pretoria 0001, South Africa. 2010.

ELSHARKAWY, A., ELHABIBY ,M., AND EL-SHEIMY, N. New combined pixel/object-based technique for efficient urban classification using WorldView-2 data. International Archives of the Photogrammetry. Remote Sensing and Spatial Information Sciences, v. 7, p. 191-195, 2012.

ERDAS. ERDAS Field Guide. Norcorss, Georgia: Leica Geosystems. 2005.

FAO. Land evaluation. Land and water discussion paper 6. Food and agriculture organization of the United Nations. Rome. 2007.

Gotway, C.A, FERGUSON, R.B, HERGERT, G.W, AND PETERSON, T.A. Comparison of Kriging and Inverse Distance methods for mapping soil parameters. Soil Science Society of America Journal, v. 60, p. 1237-1247, 1996.

HALL, R. Two cycles of land policy in South Africa: Tracing the contours. In W. Anseeuw \& C. Alden, eds. The Struggle over Land in Africa: Conflicts, Politics and Change. HSRC Press, p 175-192. 2010.

HOARE, D. Environmental impact report. Ecological study of the proposed Westgate Tarlton Kromdraai 132 kV Power Line and Substation Project for ESKOM in the Gauteng Province. ARCUS GIBB (Pty) Ltd, Rivonia. 2008.

JAMALI, A. Unconsolidated Oil Sands: Vertical Single Well SAGD Optimization. A Thesis In Petroleum Engineering. Submitted to the Graduate Faculty of Texas Tech University in Partial Fulfillment of the Requirements for the Degree of Master of Science in petroleum engineering. 2014.

KERRY. R, OLIVER, M.A, AND FROGBROOK, Z.L. Geostatistical applications for precision agriculture. International Journal of Applied Earth Observation and Geoinformation, v. 5, p. 35-64, 2010.

LILLESAND, T.M, KIEFER, R.W, AND CHIPMAN, J.W. Remote Sensing and Image Interpretation. John Wiley and Sons, Inc., 111 River Street, Hoboken: NJ, 2008. ISBN-13 978-0470052457. 2008.

MALCZEWSKI, J. GIS-based land-use suitability analysis: a critical overview. Programme Planning, v. 62, p. 3-65, 2004.

OTIENO, A.G. Design of a water treatment plant for Wanguru town, Mwea constituency, Kenya. A Fifth Year Design Project Report submitted in fulfilment of the partial requirements for the Degree of Bachelor of Science in Environmental and Biosystems Engineering, University of Nairobi-Kenya. 2013. 